\title{
INTERSTATE AUTHORITIES IN THE UNITED STATES
}

\author{
RrChaRd H. LEaCH*
}

\section{InTRODUCTTON}

While the use of the authority device within individual states has burgeoned in recent years, there has been no significant increase in its use by two or more states jointly. Indeed, although interstate action has been used more and more frequently since World War II by groups of states to provide for joint attack on a wide variety of problems, ${ }^{1}$ few interstate authorities have been created. As of this writing, there are only six true interstate authorities in the United States:

The Delaware River Joint Toll Bridge Commission

The Delaware River Port Authority

The Lake Champlain Bridge Commission

The Maine-New Hampshire Interstate Bridge Authority

The Port of New York Authority

The Tennessee-Missouri Bridge Commission

Except for the two port authorities, none of them amount to much. The TennesseeMissouri Bridge Commission, for example, until it became inactive two years ago, operated a ferry across the Mississippi River at Tiptonville, Tennessee, and employed less than a dozen men for this purpose. The Lake Champlain Bridge Commission operates two highway bridges and is studying the possibility of erecting a third over Lake Champlain. It employs only about a dozen men in its operations, and in Fiscal Year 1959 received \$18I,I55.I0 in tolls, of which it expended $\$ 85,995.3^{\circ} .^{2}$ The Maine-New Hampshire Interstate Bridge Authority operates a motor and railroad bridge over the Piscataqua River between Kittery, Maine, and Portsmouth, New Hampshire. It has around twenty full-time and ten part-time employees, and, in Fiscal Year 1960, it operated on a budget of $\$ 154,200.15$. Its total receipts from tolls and rent during the same period were $\$ 574,017.44 .^{3}$ The bonded indebtedness outstanding of the three authorities combined is only slightly over $\$ 2,000,000$.

The Delaware River Joint Toll Bridge Commission is a somewhat larger opera-

* A.B. 1944, Colorado College; A.M. 1949, Ph.D. 1951, Princeton University. Associate Professor, Department of Political Science, Duke University. Author, [with Alpheus T. Mason'] IN Quest of Frezdom: American Political Thought and Practice (1959); [with Redding S. Sugg, Jr.] The Administration of Interstate Compacts (1959); [with Robert H. Connery] The Federal Government and Metropolitan Areas (r960). Contributor to periodicals of articles chicfly in the field of American national and state government.

${ }^{1}$ See Richard H. Leach \& Redding S. Sugg, Jr., The Administration of Interstate Compacts ch. I (1959). See also Council of State Governments, Interstate Compacts 1783-1956 (1956).

a Lake Champlain Bejdee Comm'n Auditor's Rep. 5 (1960).

${ }^{3}$ Matne-New Hampshire Interstate Bridge Authority Audited Ann. Financial Rep. Fiscal Year ENDING JUNe 30, 1960, at 4 (1960). 
tion. It has jurisdiction over IIo miles of waterfront in the Delaware River valley, and maintains and operates five toll bridges and thirteen free bridges crossing the Delaware River. Its remaining outstanding indebtedness incurred in building the toll bridges amounted in $195^{8}$ to $\$ 21,918,000$; and in the same year, its operating expenses for the five toll bridges were $\$ 859,599.62$, which it paid out of receipts totalling $\$ 877,264$. The toll bridges required the services of 146 full-time people in 1958. The funds for the operation and maintenance of the free bridges are provided by state appropriation, and fifty-three additional employees were required in I958 to staff them. ${ }^{5}$

All of these agencies have a single purpose: the construction, maintenance, and operation of a single kind of public utility. By now their work has become relatively routine in nature, and they can only look forward to a quiet future since, barring amendment to the compacts which created them, they have fulfilled their mandates. The two port authorities are an entirely different matter. Both are multipurpose, and they both can envisage an increasing scope of operations in the years ahead.

The observation that four of the existing interstate authorities are small and limited in their function does not mean that these authorities do not meet a peculiar need and meet it well; or that they are not important to the party states. The evident usefulness and ability of the interstate authorities is strikingly illustrated by the fact that no party state has exercised its option under any compacts to withdraw from an authority. But beyond their activities, there is little unusual or different about them that needs to be pointed out. A great deal more could, of course, be said about the two port authorities, but even their operations fall immediately into fairly familiar patterns. For basically, the authority device, when adapted for use by two or more states, is the same in operation as when used by a single state or on the municipal level. Since considerable attention is given elsewhere to the administrative principles and techniques of the public authority in general, and to the Port of New York Authority in particular, this paper will not be concerned with the details of interstate authority operation. Rather, it will attempt first to draw some conclusions from the experiences of the existing interstate authorities with regard to peculiar problems involved in their use; it will then examine a number of interstate agencies which are quasi-authority in nature and which, therefore, ought to be accorded some sort of recognition in discussion of interstate authorities; and finally, it will deal with the possibilities for and problems involved in the wider use of the interstate authority device in the United States.

\section{I}

\section{Some Problems Faced by Interstate Authorities}

It is important to recall at the outset that by and large since its inception, the authority movement has been confined to municipal and intrastate authorities.

'Dejaware River Joint Toll Bridge Comm'n Ann. Rep. 6, 9 (1958). The i959 and ig6o reports were not available as of April, r96I.

Ibid. 
Because there are so few interstate authorities-and because they involve so few states ${ }^{\boldsymbol{b}}$-very little attention has been paid to them by students in the field. The Port of New York Authority is the only exception. ${ }^{7}$ Thus, no separate set of rules which pertains to interstate authorities alone has been developed, nor have their operations and functions been subjected to comparative analysis. The several interstate authorities which have been established were each brought into being in response to a unique set of problems. Each was the product of circumstances, not of theory. Each has been a pioneer as far as its own development has been concerned. To be sure, all six have common characteristics, but it is too early to be dogmatic in describing on the basis of those characteristics the interstate public authority. They are still too new and still too much in the process of becoming to have jelled into a distinct category.

Study of the material available ${ }^{8}$ does, however, permit a number of conclusions about interstate agencies as a type. One is impressed, first of all, by the fact that the interstate authority has more often than not been ground reluctantly out of the necessities of the case rather than adopted easily and early in the search for solution to an interstate problem. Indeed, it appears that the common pattern has been for the authority device to be used as a sort of last resort. Perhaps the most frustrating aspect of the American system of government is the irrelevance of state lines to many of the problems arising in the areas which they cross. Action by one state to solve such problems can be rendered fruitless by inaction or different action by the other states concerned. Yet cooperation is often hindered by the rigidity of state constitutions and state laws as well as by conflicts along political and emotional lines. After attempts to solve problems single-handedly have been foiled time and again, the ad hoc solution of creating an authority has often been the only remaining alternative. Certainly the Port of New York Authority was born out of desperation over a seemingly hopeless impasse between New York and New Jersey over the increasingly complex problem of transportation in the port area. It was accepted finally as the only way remaining to settle the bitter wrangling and bickering that had marred the relations between the two states. Although not as much is known about the background of the other authorities, there seems to have been in most cases there, too, a record of frustration and conflict which was finally brought to an end by the establishment of the authority.

Perhaps because of the accumulation of ill will which built up between states as they sought to solve common problems, once the authority device was finally agreed upon as the solution, it was adopted only after a great deal of study. The

- New Jersey and Peninsylvania are the parties to the Delaware River Joint Toll Bridge Commission and the Delaware River Port Authority; New York and New Jersey, to the New York Port Authority; New York and Vermont, to the Lake Champlain Bridge Commission; and the states mentioned in the titles to the other two authorities. Altogether, only eight states are involved, and New York and New Jersey are involved in four of the six authorities.

${ }^{7}$ See Port of New York Authority, A Selected Bibliography ig2i-1956 (1956).

${ }^{8}$ With regard to the four smaller authorities, the student is confined, as far as published materials are concerned, pretty much to the annual reports of the authorities. These were amplified, however, by personal correspondence by the author with the executive officials of each authority. 
states evidently wanted to be absolutely sure that what they were doing was right. At least the history of the six interstate authorities now operative in the United States reveals an impressively extensive preparation which preceded the establishment of each of them. Julius Henry Cohen, the father of the Port of New York Authority and its first general counsel, described the many steps involved in creating that authority in his autobiography; ${ }^{9}$ and although not all of the steps which he lists have been taken in every case since then, by and large it would seem that the basic process used by Cohen and his fellow-builders has become the standard for authority establishment. Given a problem to be solved by the creation of an interstate authority, Cohen concluded: "There is but one way to go about [doing] it practically, and that [is] to follow the experience in dealing with the problems of the Port of New York. First, create a Study Commission, appoint upon it men who would be expert in the various fields of knowledge involved; organize a staff of competent engineers ... . and select some lawyers to work on the complex legal problems in the situation; study the problem from all points of view" and base final action upon their recommendations. ${ }^{10}$

The process which Cohen here describes continues to be employed today. A recent example is in the case of the proposed Missouri-Kansas Development Agency for the Kansas City metropolitan area. The recommendation for the creation of that Agency to build and operate both bridges and tunnels and drainage, water supply, sewage, and garbage disposal facilities in the Kansas City area was the product of a fifteen-month study conducted along the "Cohen Process" by the Kansas City Metropolitan Area Planning Council. ${ }^{11}$ The Interstate-Federal Compact Commission for the Delaware River Basin, which was just proposed in $\mathbf{1 9 6 \mathrm { r }}$, is the result of probably the most thorough study ever made of an American river basin. In 1955, the Governors of New York, Pennsylvania, New Jersey, and Delaware, and the Mayors of New York City and Philadelphia created the Delaware River Basin Advisory Committee to review the water problem in the Basin. With the help of a number of citizens in the area, the Committee established a Water Resources Foundation for the Delaware River Basin. Financed by a grant of $\$ 131,000$ from the Ford Foundation, the Water Research Foundation in turn asked the Maxwell Graduate School of Syracuse University to make a study of the governmental organization needed for water resources, planning, development, and operation in the Basin. The completed study, entitled The Problem of Water Resources Administration, ${ }^{12}$ was presented to the Foundation on September I, 1959, and within a year, a concrete proposal for the creation of an authority was before Congress and the states. ${ }^{13}$

\footnotetext{
'Julius H. Cohen, They Builded Better Than They Knew ch. 25, esp. 281-85 (1946).

${ }^{10}$ Id. at 332.

11 American City, May 1957, p. I71.

${ }^{12}$ Revised and published under the title, Roscoe C. Martin, River Basin Administration and the Delaware (I960).

${ }^{13}$ The story is told in some detail in Water Resources Foundation for the Delaware River Basin, Special Bulletin (196r). See also, infra, text at notes 36-39.
} 
If the "Cohen Process" is still the basic way of establishing an authority, a number of auxiliaries have been developed since 1920. Enough interstate authorities have been created by now so that there is a considerable reservoir of experience upon which those seeking to develop a new authority may draw. By doing so, they may avoid some of the difficulties which plagued their predecessors. The Port of New York Authority has been particularly generous in offering help and counsel. Even more important, there now exists a body with expertise in the field of creating interstate agencies, the Council of State Governments. No discussion of interstate activities of any sort would be complete without mention of the Council. One of its functions is to assist the states in solving interstate problems. It offers help in conducting research, in drafting the interstate compacts on which authorities are based, and in advising interstate agencies once they are established. And the Commissions on Interstate Cooperation, which are the Council's arms in the several states, are available to help secure acceptance of the agency by state legislative and executive officials. ${ }^{14}$ With all these services available today, there is no doubt that the way of the authority-builder is much easier than it used to be.

Another conclusion which emerges from a study of the existing interstate authorities is that it is necessary to base an authority on an interstate compact. In Julius Henry Cohen's words: "It was clear that New York and New Jersey had to be brought into binding cooperation. Hence, there would have to be a compact between the two."15 An authority is basically an operating agency. It thus necessarily will accumulate property for that purpose, and its revenues will probably be derived from bonds secured by that property. It was obvious to Cohen, as it must be to any student of interstate relations, that without a legal barrier to prevent it, "Someday perhaps a legislature might change the policy of a State and dispose of [its] interstate property...."16 With a compact as its base, however, the authority would be protected from such an action. For although there is still no precise constitutional definition of the term, the consensus is that an interstate compact is a contract, and because of the quasi-sovereign nature of the parties to a compact, it is regarded as a more formal and weighty commitment than a contract involving private persons. ${ }^{17}$ Indeed, the Supreme Court has held in the landmark case of West Virgina ex rel. Dyer $v$. Sims ${ }^{18}$ that the delegation by compact of power to an interstate agency amounts to an irrevocable commitment, at least where there is no specific state constitutional provision prohibiting such delegation. A state generally may not, the Court has declared, withdraw from a compact on the grounds that the delegation was, after all, contrary to her constitution, for she has entered into a contractual obligation not lightly to be broken. And the late Mr. Justice Jackson stated in his concurring opinion in the same case: "West Virginia, for internal affairs, is free to interpret her own Constitution as she will. But if the Compact

\footnotetext{
${ }^{14}$ See Zimmerman \& Leach, The Commissions on Interstate Cooperation, 33 State Gov, 233 (1960).

${ }^{15}$ CoHEN, op. cit. supra note 9, at 290. (Emphasis added.)

${ }^{10}$ Ibid.

${ }^{17}$ Cf. Virginia v. Tennessee, 148 U.S. 503 (1893).

${ }^{18} 34 \mathrm{I}$ U.S. 22 (1950).
} 
system is to have vitality and integrity, she may not (retroactively) raise an issue of ultra vires, decide it, and release herself from an interstate obligation."19 As a result of this decision, interstate agencies may operate on a permanent basis, once they are established, and the Supreme Court can be expected to sustain the compacts creating them whenever they are attacked on the grounds of technical defects under the internal constitutional law of a member state which were not apparent at the time of the Congressional approval of the compact. Of course, a state may withdraw from the compact in accordance with the procedure set out therein, but for the duration of the compact, she cannot forsake the agency.

Moreover, establishment through a compact assures easier and more effective administration, since one body will be created to serve as the compact's administrative arm, rather than two or more separate commissions operating in each of the party states.

For both these reasons, compacts have become a basic ingredient of the interstate authority recipe. This, however, has not proved to be an unmixed blessing. For the compact device involves difficulties of its own. Not only are compacts often hard to formulate, but they are also often difficult to get ratified. Congress, which must generally give its consent, ${ }^{20}$ has not been as hospitable towards compacts as might be expected, ${ }^{21}$ and often what sounds eminently reasonable to the negotiators of a compact may fail to impress a state legislature at all. And once in force, compacts are often hard to amend. Thus, although it was obvious to the Illinois legislature as early as I953, when it approved authorizing legislation, that the Bi-State Development Compact needed to be amended in order to make the Bi-State Development Agency truly an effective instrument of government, the Missouri legislature was not convinced of the same necessity until 1959. In the intervening six years, the Agency operated with much less return to the states than it might have. Moreover, compacts are sometimes hard to enforce, existing as they do in a sort of no-man's land between the regular administrative agencies of the party states. Except in extremis, judicial enforcement has little to recommend it.

It is true that these disadvantages of compacts are present for whatever purpose the compacts are used. But they are particularly important in the case of authorities because of the operational nature of their "compactual" mandates. The need for amendment, for example, of a compact creating a recommendatory or study agency may not be as confining as the same need in the case of a compact creating an operating authority. In the latter case, for full effectiveness, the limitations imposed on the actions of the authority must necessarily be overcome. The history of the interstate authorities in the United States reveals enough examples of the necessity of changing compacts as new situations or conditions not covered in the original compact have arisen, to indicate that the problem is a real one. The jurisdiction,

${ }^{10}$ Id. at 35 .

20 ". . . no State shall, without the consent of Congress . . . enter into any agreement or compact with another State ...." U.S. ConsT. art. I, $\$$ Io.

${ }^{31}$ See Leach, The Status of Interstate Compacts Today, 32 State Gov. 134 (1959). See also Leach, The Federal Government and Interstate Compacts, 29 FordHaM L. Rev. $42 \mathrm{I}$ (rg6r). 
duties, and powers of the Delaware River Joint Toll Bridge Commission, which was established by compact in 1934, have several times had to be enlarged since then in order to keep the Commission fully effective. Similarly, several years of trying to work under the original compact creating the Bi-State Development Agency convinced both the Agency staff and finally the legislatures of the two party states that a number of modifications in the compact were necessary if the Agency was to carry out its functions properly. The compact creating the Lake Champlain Bridge Commission, adopted in 1927 , has been amended five times, most recently in 1958 . Other examples could be cited. The moral of the story probably is that special care is necessary in drawing up authority compacts; and that they should be examined from time to time for assurance that their terms still enable the authority to function efficiently.

Perhaps the biggest problem facing interstate authorities, once the compact has been drawn and ratified and they have become operative, is the problem of identifying themselves and relating their work to the rest of the governmental machinery in the party states. Indeed, Cohen might well have added one further step to his procedure to develop an interstate authority-the need to seek political and administrative, to say nothing of public, acceptance of the device. Too often, an authority, once established, has been left unrelated to the activities of regular state departments and agencies. Only a few states have done anything to tic their interstate agencies formally to their regular administrative organization. In Missouri, the Bi-State Development Agency and the Tennessee-Missouri Bridge Commission have been brought under the state Department of Business and Administration. But that is about as far as the movement has gone. And even in Missouri, it must be said, the connection thus provided evidently did not succeed in bringing those agencies into a very close relationship with the rest of the state government. At least, the Governor's Office was unaware in the spring of $196 \mathrm{r}$ either that the offices of the Bi-State Development Agency in St. Louis had been moved several months before, or that the Agency had acquired a new Executive Director. Most of the states have simply ignored their interstate agencies altogether.

As a result of their unclear, in-between sort of status in the state administrative setup, interstate authorities operate with considerable freedom. Perhaps because the authorities do not ordinarily make demands upon the state treasuries and because they confine their activities to specialized fields of endeavor, the states have not sought to impose strict controls on them. All compacts become part of the law of each party state upon ratification, and all compact agencies thus automatically become agencies of each state. Because they do, devices for control, supervision, and direction which may be brought to bear upon intrastate agencies may also be brought to bear on interstate authorities, except where the compact provides otherwise. The compacts creating authorities are full of additional provisions designed to enable the states to restrain them in action-reporting provisions, the requirement that the authority's books be made available for inspection or audit by authorized repre- 
sentatives of the state or by private auditing firms, a veto power over the authority's actions vested in the governor, provisions for removal of officers found guilty of malfeasance in office, the requirement of legislative approval of comprehensive and supplemental plans, and still others. Despite the availability of this arsenal of possible controls, however, the states by and large leave the authorities they have: created alone.

To some extent, of course, this freedom is desirable. Indeed, part of the justification for creating an authority in preference to some other governmental device is to gain just such freedom. But that very freedom necessitates care on the: part of each authority to relate itself to the people and to the officials of the party states in order to allay fears that the authority is inimical to the democratic process. Even at the outset, this problem was recognized. Julius Henry Cohen, in talking about the early days of the Port of New York Authority, remarked that it was generally felt when that agency was first created that the word "authority" must have been chosen with malice aforethought, that it "must mean a supergovernment! We became a sort of Halloween spectre to the municipal officials of all the cities. within the [Port] District . . . ready to capture all the little children, push them into our oven and make gingerbread out of them." ${ }^{22}$ In an attempt to dispel this belief, the Port Authority early developed an extensive public relations program. Much of its later success can be attributed to the work of Mrs. Belle Moskowitz, its. first public relations counsellor. ${ }^{23}$

The experience of the Port Authority has been repeated with each of the other interstate authorities. Unrelated to the rest of the state machinery, they have had to. make themselves known to the public as a whole, and to develop for themselves. whatever relations with the party governments seemed necessary or practical. Through brochures, by making their staff available for speeches and public appearances, and by taking the initiative in developing personal ties with legislators and. executive officials in the states, the authorities have gradually become known and. have been accorded some degree of recognition as public agencies both in and out. of government circles. These public relations programs have been more successful in bringing about closer contact with and awareness of the interstate authorities in the executive than in the legislative branches of the states, where size and turnover make the problem of education much more difficult. In no state, however, even in the executive branch, has a single official or department been specifically charged with maintaining liaison with the interstate authorities to which that state is party, despite the fact that in law every authority is a state instrumentality of each of the party states, and that it is a basic principle of public administration that some line of control should link all the units of a single administrative system. Although numerous contacts have been established, this has been achieved through the action of the authority rather than by the efforts of the states. Not only are these contacts

\footnotetext{
${ }^{22}$ CoHen, op. cit. supra note 9 , at $29 \mathrm{x}$.

${ }^{23}$ Id. at $248-49$.
} 
thus unilateral, but they are also haphazard, depending upon individual empathy for the most part.

It is hard to assay the effect on the authorities of existence in an administrative limbo, and of having to blow their own horns for attention. There is no doubt that some of the resources of the authorities which might otherwise be devoted to program activities are diverted to public relations instead. There is always the danger that in such a unilateral arrangement, abuse will grow and develop. It is reassuring to note, however, that in the one instance where abuses did develop-in the case of the Delaware River Joint Toll Bridge Commissioners who appropriated Commission funds to their own uses-the matter was handled quickly and efficiently by the governors and courts of the party states. ${ }^{24}$ At the least, the ambiguous position of interstate authorities in the administrative setup creates a continuing problem in the effective accomplishment of their program goals. At the same time, it presents a challenge to students of public administration and to the officers of states party to an interstate authority, a challenge which should soon be both accepted and reduced to size.

\section{II}

\section{INTERSTATE QuASI-AUTHORITIES}

The true authority, Austin J. Tobin insists, ${ }^{25}$ is self supporting, and Mr. Tobin's rule is generally accepted as correct, and has been followed in part one. But total selfsupport is perhaps too much to require of an authority. Even the Port of New York Authority launched its program with appropriations from the states (which it later paid back in full); and the Lake Champlain Bridge Commission not only was advanced $\$ 200,000$ by its parent states at the outset, but later received a PWA grant of $\$ 343, \mathrm{r} 30.63$ in addition. ${ }^{28}$ There are undoubtedly many interstate problems for the solution of which a self-supporting authority operation is the obvious answer. It is equally likely, however-and indeed often the case-that states may want to join in attacking a problem but wish to refrain from creating a financially independent unit of government as their instrument. To define the public authority too rigidly serves to make its several advantages less than freely available to the states. It would seem preferable to adopt a more comprehensive definition encompassing agencies financed in a variety of ways.

If this broader definition be used, there are a number of interstate agencies which while they do not meet the self-support test, nevertheless are to some degree independent in terms of support; and which meet the other generally accepted qualifications for an authority in that they are "set up outside the regular framework of ... government ... freed from the procedures and restrictions of routine government operations and [managed according to] the best techniques of private management. ..."27 Because these agencies perform important governmental func-

\footnotetext{
${ }^{24}$ Delaware River Joint Toll Bridge Comm'n ANN. Rep. it (1958).

${ }^{25}$ Austin J. Tobin, Authorities as a Governmental Technique 15 (1953).

${ }^{26}$ Lake Champlain Bridge Comm'n Auditor's Rep. 2 (I960).

27 ToBIn, op. cit. supra note 25 , at 15 .
} 
tions and because they are at least of a quasi-authority character, they must be included in a discussion of interstate authorities.

The Waterfront Commission of New York Harbor, for example, is supported by the assessments which it makes on employers of persons licensed and registered under the terms of the compact. Although it operates thirteen employment information centers in the New York waterfront area, it is not a business enterprise in the sense that it operates a public work or facility. Rather, it performs what is basically a police function for the party states. It does so independently of regular political controls, with its own personnel and procedures, and at no cost to the state treasuries. Only because it does operate in this way-only because it is, in other words, essentially an authority - has it been able to cope successfully with the problem of crime on the New York waterfront. For the Commission, since it began to operate in 1953, has succeeded where every one else had failed for half a century. The dramatic reduction of theft and violence on the docks, the abolition of the notorious "shape-up," the elimination of extortion by "public loading"-all these have come about as a result of the Commission's efforts. It is generally credited with making an outstanding contribution to the welfare of the citizens not only of New York and New Jersey, but to that of everyone who uses the New York docks. ${ }^{28}$

Similarly, the Breaks Interstate Park Commission of Virginia and Kentucky and the Palisades Interstate Park Commission of New York and New Jersey, both financed chiefly through legislative appropriations and gifts, would not be classifiable as authorities under a narrow definition of that term. But if judged by their operations, they are both authorities.

Although the compact creating the Breaks Interstate Park Commission provides that the cost of developing the park may be defrayed by the issuance of revenue bonds, the states have not chosen to use that power. Instead, much of the land under development was donated to the Commission, and its day to day work is wholly paid for on a fifty-fifty basis by appropriations from the legislatures of the two states. But the Park Commissioners have full control of all aspects of park development and operation, and political strife has been avoided completely to date. $^{20}$ As of r $196 \mathrm{r}$, a park of 1,625 acres had been developed, and plans were in the making for the addition of another 2,375 acres. The area in which the park is located is one rich in legend and colorful pioneer history. When it is completed, it will provide a variety of recreational facilities for the residents of the entire southwestern corner of Virginia and of Eastern Kentucky.

Unlike the Breaks Commission, the Palisades Interstate Park Commission has no. independent borrowing power of its own. It receives its income from a combination of sources: appropriations, gifts, income from its facilities, the proceeds of bond issues floated by the party states, and voluntary state services. The Commission is free, however, to plan, develop, maintain, govern, and manage the Park as it sees fit; freed from the restrictions imposed by either state on its own state agencies; and

${ }^{28}$ LeACH \& SuGG, op. cit. stupra note 1 , at 187 -I95.

${ }^{29}$ The Breaks Interstate Park, The Commonwealth, Oct. I957, p. I7. 
entirely beyond the machinations of local politics. It now operates what is un.doubtedly one of the finest park systems in the United States, comprising some 53,000 acres along the Palisades of the Hudson, and providing recreational outlets for the millions of people in the New York metropolitan area. ${ }^{30}$

In addition to the agencies which we have designated quasi-authorities because of the ways by which they are financed, there are other interstate agencies which are authorities in name but are quasi-authorities in fact because of the kind of functions they actually perform. Students of the authority agree generally that the device is to be used "for the management of public enterprise," which, defined specifically, includes ports, bridges, tunnels, toll roads, terminals, markets, airports, housing projects, and public utilities. ${ }^{31}$ However, at least two important interstate agencies, while endowed by their compacts with operating powers and thus technically qualified as authorities, have in practice made little or no use of those powers. In terms of function, they would thus be described as study and recommendatory agencies. ${ }^{32}$ These two agencies are the Bi-State Development Agency and the Southern Regional Education Board.

The Bi-State Development Agency was created by compact between Illinois and Missouri in 1949 to provide "cooperation in the future planning and development of the St. Louis metropolitan area." ${ }^{33}$ Although it was authorized by the compact to own and operate bridges, tunnels, airports, wharves, docks and harbors, warehouses and other storage facilities, grain elevators, sewage disposal plants, and passenger transportation and terminal facilities, it has so far emphasized in its work the planning and recommendatory function. Its Mississippi River Pollution Survey, its Highway and Expressway Survey, and its St. Louis County Sewer Survey are all masterpieces of their kind. All of them were financed by grants to the Agency, and the Agency confined its role to facilitating action on the recommendations embodied in the various surveys by local and state governmental units. Indeed, the Agency has purposely kept itself small, and has adopted the policy of using outside consultants and acting through contracts with other organizations rather than of developing an operational staff of its own. ${ }^{34}$ Even when it set out to develop a $.4,200,000$ bushel grain elevator adjacent to its wharf, it did so by contract with the Illinois Grain Corporation rather than on its own. So far the only facility built for the Agency's own operation-financed by revenue bonds-has been the -Granite City Wharf, the construction of which cost $\$ 1,500,000$. Although the Agency enjoys the power to borrow money, it has so far preferred to operate without using this power. There is a possibility that the Agency might take over the mass transit

${ }^{\text {so }}$ For a description both of the Park and its operation facilities, see Palisades Interstate Park 'Comm'n, 6o Yeats of Park Cooperation (I960).

${ }^{31}$ See, e.g., address by Austin J. Tobin, The Public Authority-An Aid to Economic Development, delivered to the Economic Development Institute, Washington, D.C., May 15, 1956, New York Port Authority Release, p. $x$.

${ }^{32}$ See Leach \& SugG, op. cit. supra note I, at I8-20.

${ }^{33}$ The Bi-State Development Agency, Missouri-Illinols Metropolitan District I (ig6o).

${ }^{34}$ Letter from Col. R. E. Smyser, Jr., Exec. Dir., Bi-State Development Agency, to Richard H. Leach, April 3, 196r. 
lines in the St. Louis area. If it should, of course, it would acquire a major operating function. The Board of Commissioners of the Agency, however, has not yet decided on the matter. Even with its recently added operational activities, the major contribution of the Agency to the St. Louis area will probably remain for some time the vigorous leadership it has given to area-wide planning.

The compact establishing the Southern Regional Education Board, now subscribed to by sixteen southern states, speaks of "the establishment, acquisition, operation and maintenance of regional educational schools and institutions for the benefit of the respective states." ${ }^{35}$ The framers of the compact, in fact, were confident that this would be the primary function of the Board. However, the Board itself at its first meeting adopted by-laws which emphasized working with existing, accredited colleges and universities in the region, thus obviating the necessity of creating and operating new regional institutions. And it has not deviated from that policy since. Thus the Board is not an authority, not because it cannot serve as an operating agency engaged in a "public enterprise," but because it has chosen to work in the planning and research areas and leave the actual operation of educational institutions in the hands of existing colleges and universities in the southern region.

The most recent interstate agency may also not turn out to be an authority. The Delaware River Basin Commission is charged in general with the management and control of the water and related natural resources of the 12,750 square mile Delaware River Basin. Specifically, it is to "develop and effectuate plans, policies and projects relating to the water resources of the basin. It shall adopt and promote uniform and coordinated policies for water conservation, control, use and management in the basin. It shall encourage the planning, development and financing of water resources projects according to such plans and policies."36 As the compact reads, the Commission's chief concern will be with developing a comprehensive plan for basin development, and with providing common direction to the "operations of the ig Federal agencies and approximately 60 State agencies which are concerned to some degree with the water resources of the basin. ..."37 The Commission's activities would be financed by appropriations, grants, and loans; indeed, the longest section of the compact deals with capital financing.8 ${ }^{38}$ It is thus possible that the Commission's activities may extend into the operating field. Several specific provisions in a number of articles grant the Commission power to construct and operate facilities. For example, article 4, which deals with water supply, says in part: "The commission shall have power to develop, implement and effectuate plans and projects for the use of the waters of the basin... To this end, without limitation thereto, ${ }^{39}$ it may provide for, construct, acquire, operate and maintain dams, reservoirs and other facilities. ..." And article 5, dealing with

\footnotetext{
as Southern Regional Education Compact art. $I$.

${ }^{86}$ Interstate-Federai Compact, Delaware River Basin art. 3, \$ I, 75 Stat. 688, 692 (Sept. 27, 1961).

${ }^{87}$ Io8 Cong. Rec. I768 (daily ed. Feb. I, I96I).

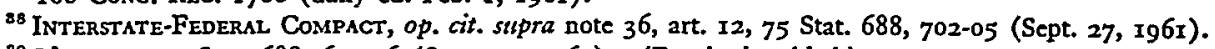

${ }^{30}$ Id. art. 4, 75 Stat. 688, 695-96 (Sept. 27, 196r). (Emphasis added.)
} 
pollution control, repeats almost the same phraseology, as does article 8, dealing with recreation. The latter article declares that "the commission shall provide for the development of water related public sports and recreational facilities. The Commission on its own account or in cooperation with a signatory party ... may provide for the construction, maintenance, and administration of such facilities...."

Only time will tell what the proposed Commission will in fact become. It seems likely, however, that it will follow at first at least the pattern established by the BiState Development Agency and the Southern Regional Education Board, and emphasize its planning and coordination functions rather than the operational function. The development of the comprehensive plan will obviously be the first task which the Commission will undertake.

Such interstate agencies are thus hybrids-they are authorities and they are not. And the same moral should be drawn here as with regard to variations in financing: it is good that this is so. For surely, for its full effectiveness, the authority device should be kept flexible in operation and adaptable in purpose. The proper course of action would seem to be the creation of interstate agencies under compactual mandates which do not obligate them to embark at once upon a specific enterprise or enterprises, but which nevertheless enable them to do so if needs be. Established in this way, such agencies can be of greater value to the party states than authorities narrowly restricted from the outset to a specific kind of operation, because only the former can grow and change in response to changing needs.

\section{III}

\section{Interstate Authorities: Future Prospects}

There are good reasons to believe that the interstate authority has a very bright future. Indeed, it appears that the peculiar concatenation of circumstances which justifies the establishment of interstate authorities is arising ever more frequently, and that an increase in their number can be expected in the years ahead. It is in fact quite possible that the interstate authority will become the most common type of interstate body in the United States.

For by and large, the conditions which have brought about the creation of the most important interstate authorities to date are the product of increased urbanization-the result, in short, of the growth of metropolitan areas in this country. It is not mere coincidence that the first interstate authority to be created in the United States was the Port of New York Authority, or that the Port of London Authority was its predecessor. Both were brought into being in order to solve problems arising in rapidly growing urban areas. The same is true of the Bi-State -Development Agency and the proposed Delaware River Basin Commission. Today, the steadily and rapidly growing concentration of two-thirds of the nation's population into 192 metropolitan areas is perhaps the most dramatic event on the 
American scene, and unless all the prognostications about future population growth in the United States are wrong, the future holds only a continuation of the process.

Metropolitanization brings in its wake a host of administrative problems related to the services performed for urban residents by state and local governments. Luther Gulick recently described the compound of problems resulting from the new metropolitan way of living as a problem in discontent: ${ }^{40}$

People are not satisfied with their homes and housing, with their trip to and from work, and with the aggravations, costs and delays of traffic and parking. They are distraught by the lack of schools and recreational facilities for their children and themselves, and they are concerned by .... neighborhood conditions, youthful delinquency and crime. People find shopping difficult and more regimented, and the ever more needed services hard to get and expensive. They struggle with water shortages, with bad drainage, and sewer conditions, with dirt and noise which they don't like. They find the city centers 'old style,' inconvenient, dismal and repulsive and the old buses, streetcars, trains and other methods of mass movement uncomfortable and slow.... And when people move to the suburbs and take work in a new suburban factory, store or other enterprise, they find that many of the evils they sought to escape move in right after them, with mounting taxes to plague them there too.

Obviously, population shifts on such a vast scale make unprecedented demands on the resources of governmental units in urban areas. Unfortunately, this comes at a time when governments in metropolitan centers are still trying to solve the problems of their earlier growth. Already, millions of urban residents live in substandard housing; their children are packed into old-fashioned schools; they drive on narrow and crowded streets; and they are served by inadequate mass transportation, water and sewage facilities. In the face of these combined demands-to eliminate the evils of the past and to prevent their future occurrence-there is hardly a city in the nation that has the economic resources to launch a successful attack on metropolitan problems by itself.

Hard-pressed urban communities can, of course, turn to the states for help; and there are a number of things which states can do to alleviate urban problems. ${ }^{41}$ But their financial resources are limited, too. The tax advantage lies ever more with the federal government. This has meant for the states a contracting area of potential tax sources with which to meet an expanding number of demands. In fact, the tax situation alone raises considerable doubt whether a state, acting alone, could sufficiently help its urban areas solve their problems.

Faced thus with a metropolitan situation increasingly demanding attention, and inadequate resources with which to meet it, the states may well turn to joint action as a way out. They may, in other words, seek to develop the interstate authority as at least a partial answer to the problem of financing necessary metropolitan programs. For even a cursory study of the nation's metropolitan areas reveals that many of these,

\footnotetext{
${ }^{10}$ Luther Gulick, Problems of United States Economic Development, in Problems of United States Economic Development $x, 2$ (I958).

${ }^{4}$ Robert H. Connery \& Richard H. Leach, The Federal Government and Metropolitan Areas I30-31, I94-95, I99, 223 (I960).
} 
among them some of the most important urban centers, are not within the jurisdiction of any one state. Some fifty key metropolitan areas either extend across state boundary lines or border very closely thereon. The St. Louis, Kansas City, Youngstown, Huntington-Ashland, Cincinnati, and New York areas are but a few scattered examples. Even in 1950, one out of every four Americans lived in an interstate area, and the proportion is still higher today. Speculating on the implications of these facts, Daniel R. Grant concluded that "with the bulk of our population increase presently taking place in the suburban fringes of metropolitan areas, there may well be more people living in interstate metropolitan areas than in intrastate cities of all sizes within the next generation or two."42 If Professor Grant's conclusion is correct-and all the evidence points that way-the authority device will no doubt become increasingly attractive to states plagued with metropolitan problems.

It is not difficult to suggest problem areas for authorities. Almost every rapidly urbanizing center suffers to some degree from a lack of sufficient water. Increased urbanization brings with it problems of water pollution and sewage and waste disposal on such a vast scale that the House Committee on Public Works estimated that municipal pollution abatement fund requirements between 1955 and 1965 alone would total $\$ 5.33$ billion. ${ }^{43}$ Air pollution, although a relatively new phenomenon, has already reached alarming proportions in many urban areas. Most metropolitan areas suffer from the inability of old mass transit systems to handle present traffic, to say nothing of meeting future transportation requirements. Parking and highway problems offer further challenges. In solving one or all of these problems, the use of an authority - of the planning and recommendatory or the operating type, or, as suggested above, combining both functions-presents interesting possibilities. Indeed, in a recent discussion of financing urban public works, Mabel Walker declared that "the case for an interstate ... agency is stronger than [the case] for an agency that carries on all its activities within one state."44 As an answer to financing many of the services needed in metropolitan areas now and in the future, the authority seems to have a great deal to recommend it.

The authority solution, however, must not be regarded as a panacea for interstate problems. Too frequent recourse to the single purpose authority succeeds only in fragmenting functions which by their very nature ought to be integrated on an area-wide basis. Even multiple purpose authorities are subject to the same malady. Thus the Port of New York Authority does not deal with all aspects of transportation in the New York metropolitan area. It is not concerned, for example, with railroad transportation or with traffic in New York City, both vital parts of the overall transportation problem in the area. Moreover, there is little doubt that the special district, of which the interstate authority is but one type, further weakens and

\footnotetext{
${ }^{12}$ Grant, The Government of Interstate Metropolitan Areas, 8 WEST. PoL. Q. 90 (1955). The entire article is well worth reading in this connection.

${ }^{4}$ House Comm. on Public Works, Extending and Strengthening the Water Pollution Control Act, H.R. Rep. No. 2rgo, 84th Cong., 2d Sess. 3 (1956).

"Walker, The Authority Device for Planning Public Works, Tax Policy, Dec. 1958, p. 4.
} 
subdivides citizen interest in government, which is already so low on the state and local level as to cause concern to those interested in the continued vitality of the democratic system. ${ }^{45}$ Finally, an authority should of course not be used to displace effectively functioning state or local agencies. It is designed primarily to enable states to meet problems of planning, coordination, and financing, and it should be used accordingly. ${ }^{46}$

One objection to the use of the authority device can easily be disposed of. That is the charge that authorities act irresponsibly and are particularly subject to abuse, being offshore from the terra firma of ordinary political controls. ${ }^{47}$ There is very little on the record to justify such misgivings. On the contrary, the performance record at least of the existing interstate authorities is such that it demands respect for their efficiency and responsiveness to the needs of the areas which they serve. ${ }^{48}$ Only one authority-the Delaware River Joint Toll Bridge Commission-has ever shown any signs of irresponsible action, and that authority took steps to clean its own house. An authority, interstate or local, like any governmental agency, will reflect in its operations the caliber of its leaders. One but needs to glance at the names of the members of the Port of New York Authority, of the Delaware River Port Authority, or of any of the other interstate authorities, to know that the agency's business is in good hands. Indeed, study of the operations and programs of the several authorities discussed herein yields the conclusion that there are few governmental agencies in the United States which are better administered-i.e., administered from the point of view of the public interest. That is to say a great deal.

Regarded properly, the authority device should be an alternative available to the states when they seek freedom to develop joint solutions to common problems outside the regular framework of state government. The possibility of that alternative exists because the federal system is Alexible enough to accommodate options other than action by individual states or by the federal government. Thus far, the interstate authority alternative has not been widely used. The efficiency with which the few existing interstate authorities are now meeting their assigned responsibilities, and the increasing number of interstate problems which demand cooperative action for their solution both seem to suggest, however, that far greater use may be made of the device in the years ahead. If this should turn out to be the case, all the evidence presently available leads to the conclusion that the future will see the interstate authority come to occupy an important place in the pattern of American government.

\footnotetext{
${ }^{2}$ See Downgrading the Authorities, American City, Nov. 1956, p. 5 .

${ }^{\circ}$ See Gerwig, Public Authorities: Legislative Panacea, 5 J. Pub. L. 391 (1956).

"7 This argument is forcefully put in Cameron, Whose Authority?, Atlantic Monthly, Aug. 1959,

${ }^{48}$ See Leach, Interstate Agencies and Effective Administration, 34 State Gov. I99 (I96r).
} p. 38 . 